\title{
Hatch date distributions of young-of-year haddock Melanogrammus aeglefinus in the Gulf of Maine/ Georges Bank region: implications for recruitment
}

\author{
Amy Lapolla, Lawrence J. Buckley*
}

University of Rhode Island/National Oceanic and Atmospheric Administration Cooperative Marine Education and Research (URI/NOAA CMER) Program, Graduate School Of Oceanography, South Ferry Road, Narragansett, Rhode Island 02882, USA

\begin{abstract}
We determined the hatch dates of young-of-year (YOY) juveniles from the 1995 to 1999 year-classes of haddock Melanogrammus aeglefinus collected in the Northeast Fisheries Science Center fall groundfish surveys in the Gulf of Maine/Georges Bank region. Hatch dates were based on age estimates made by counting otolith daily rings. The average YOY haddock was $>200 \mathrm{~d}$ old at the time of capture, with estimated hatch dates ranging from mid November to early June. Haddock collected in the Gulf of Maine had mean hatch dates about 1 mo later than fish collected on Georges Bank. Each year on Georges Bank, hatch date frequencies (HDF) of survivors peaked between February and mid March, considerably earlier than the peak in HDF estimated from late-stage eggs. The ratio of the relative HDF of survivors collected in the fall to the relative HDF estimated from late-stage eggs was used to calculate relative survivorship of different cohorts. These data suggest that haddock hatched early in the season had a survival advantage over those hatched later in the year. The 1998 year-class, the largest produced on Georges Bank in the past $20 \mathrm{yr}$, had one of the latest peaks in HDF of juveniles among the 5 years examined. More survivors were produced in each month of 1998 compared to the monthly averages of the remaining years. In particular, the 1998 year-class benefited from enhanced survival of individuals hatched in the mid and latter portions of the hatch curve, although survival was still highest for individuals originating from the early portion of the hatching curve.
\end{abstract}

KEY WORDS: Georges Bank · Hatch date distributions · Juvenile haddock · Otolith microstructure · Recruitment

Resale or republication not permitted without written consent of the publisher

\section{INTRODUCTION}

Haddock Melanogrammus aeglefinus on Georges Bank and the Gulf of Maine have been a major fishery resource for the United States and Canada (Overholtz \& Tyler 1985, Brown \& Munroe 2000). They are also ecologically important members of North Atlantic demersal communities. Due to their commercial and ecological importance, there is a large body of literature examining recruitment processes of haddock and other gadoid species. This literature focuses on a variety of factors including the effects of egg and larval transport (Polacheck et al. 1992), larval and early juvenile growth (Campana 1996), density-dependent growth and mortality (Ross \& Nelson 1992), and habitat selection (Lough et al. 1989) on recruitment variability. These studies highlight the complexity of recruitment processes and the great difficulty of predicting year-class strength.

Recruitment is a result of the interaction of environmental (temperature, food availability, habitat suitability, retention, transport) and biological variables (spawning stock structure, condition, biomass, interand intra-specific competition and predation). Events during several life stages can significantly influence recruitment levels (Kendall et al. 1996). The importance of the juvenile life stage in gadoid recruitment has been implicated in several studies. For Atlantic cod 
Gadus morhua and walleye pollock Theragra chalcogramma, size at age and growth during the early juvenile period were positively correlated with recruitment, while no significant correlation was observed among these variables during the larval period (Bailey et al. 1996, Campana 1996). Sissenwine (1984) suggested that, while daily mortality rates were considerably higher during the larval period, total mortality could be higher during the juvenile stage due to the much longer stage duration.

Regardless of whether the egg, larval, or juvenile life stage is responsible for most of the variability in recruitment, relative year-class size is fairly well determined by the end of the first year of life (Sissenwine 1984). Therefore, estimates of the hatch date distributions and growth rates of young-of-year (YOY) juveniles caught late in their first year may be instructive in understanding recruitment, particularly when these are compared to hatch dates and growth estimates based on earlier life stages or examined in conjunction with extensive environmental data collected over the same period.

We aged almost 500 YOY juveniles collected during the autumns of 1995 to 1999 on Georges Bank and the Gulf of Maine to: (1) identify hatch date distributions for each year and for each putative spawning stock, (2) calculate mean daily growth rates of these juveniles, (3) compare these data between year-classes and putative spawning stocks, and (4) compare these data with available data on hatch dates based on late-stage eggs. The primary goal of this study was to identify temporal patterns in hatch date frequency (HDF) and relative survival that may provide insight into the processes affecting haddock recruitment. Future work should include comparison of hatch date and catch distributions of juveniles to spatiotemporal environmental data collected during the same years through the US Global Ocean Ecosystems Dynamics (GLOBEC): Northwest Atlantic-Georges Bank Program.

\section{MATERIALS AND METHODS}

Field collections. YOY haddock were collected from 1995 through 1999 during the NOAA/NMFS Northeast Fisheries Science Center (NEFSC) autumn bottom trawl surveys, aboard RV 'Albatross IV', using a \#36 Yankee otter trawl lined in the codend and upper belly with $7 \mathrm{~mm}$ hexagonal mesh. Sampling in the Gulf of Maine (GOM)/Georges Bank (GB) region occurred between mid September and the first week of November each year. YOY haddock were caught throughout the GOM/GB region (Fig. 1). The survey employs a stratified random design and covers the region from Cape Hatteras to the Scotian Shelf at depths between

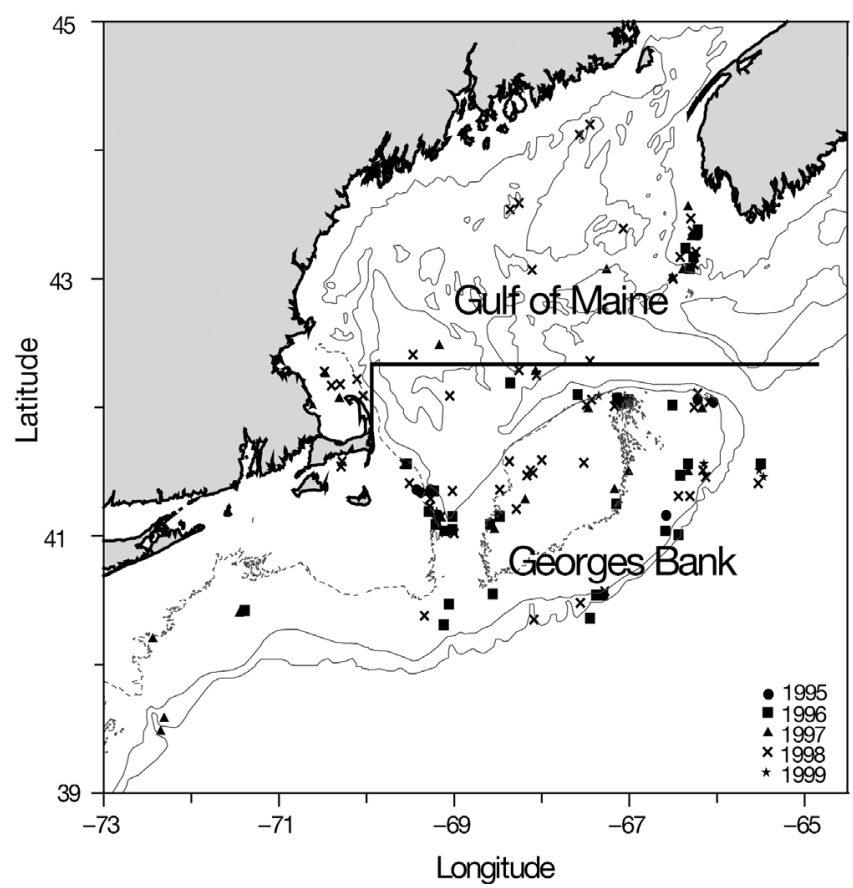

Fig. 1. Melanogrammus aeglefinus. Georges Bank and the Gulf of Maine showing stations where young-of-year (YOY) juvenile haddock were collected during the NEFSC fall groundfish surveys, 1995 to 1999. Stations trawled where YOY haddock were not collected are not shown

27 and $200 \mathrm{~m}$ (Azarovitz 1981). Sampling effort was roughly equal among years and all available YOY juvenile haddock were analyzed each year.

Minimum retention size of juvenile fish with this gear is 3.1 to $3.7 \mathrm{~cm}$ (Lough \& Potter 1993), well below the size of YOY haddock by the fall. While the bottom trawl may not be particularly efficient at catching YOY juvenile haddock, there is little reason to believe that the gear is size selective within the narrow range of sizes expected for YOY haddock in the fall survey. If anything, based on visual observations of abundance and behavior from submersibles and day/night bottom trawl comparisons, larger juveniles may escape under the trawl, particularly during the day, when they stay closer to the bottom (Lough \& Potter 1993). The NEFSC fall groundfish survey was designed to obtain quantitative abundance estimates of demersal fisheries resources within the area of coverage. Moreover, there is a significant correlation between the stratified mean catch per tow of YOY juvenile haddock in the fall survey and estimated recruitment to Age 1 or 2 based on virtual population analysis (Werner et al. 1999, Brown \& Munroe 2000). This correlation between YOY abundance and recruitment suggests not only that the critical mortality determining year-class size in GB haddock occurs sometime before the fall survey, but also that the fall survey catches YOY haddock in some 
fairly constant proportion to their actual abundance. While for most years, other than 1998, our sample size was relatively small (mean $=63$ fish), taken together, the 5 years of data should provide a reasonably accurate picture of the hatch date distributions of YOY haddock in the study area.

Fork length was measured to the nearest centimeter upon capture and the fish were frozen for transport to the laboratory. At the laboratory, fish were thawed and sagittal otoliths were removed and stored in paper envelopes marked with cruise and station numbers, fork length and fish identification number (J. Burnett pers. comm.).

Otolith analysis. All available YOY haddock otoliths from these cruises were mounted in wax and thinly cross-sectioned in the transverse plane using a doublebladed Isomet saw. The cross-sections were then mounted in thermoplastic (Crystal-Bond), and polished with wet 400 to 600 grit sandpaper followed by wet crocus-cloth (3M), with periodic monitoring beneath a compound light microscope at $100 \times$ magnification. The cross-sections were then rinsed and wiped clean, and etched with EDTA for approximately $5 \mathrm{~min}$. To count the daily increments, otoliths were covered with a thin layer of immersion oil, and illuminated from beneath with a compound light microscope. All increments were counted at $400 \times$ magnification. To avoid bias, the otoliths from all 5 years were randomized, and the year and station of a given otolith were hidden from the counter. A total of 484 otoliths were successfully aged by this method.

On most otoliths, there was a central amorphous region within which daily increments were not discernible. This problem was resolved by measuring the diameter $(\mu \mathrm{m})$ of the amorphous area for each juvenile otolith across the long axis of the transverse section, and by estimating the number of daily increments in that area using an equation relating otolith diameter and ring counts in larval haddock collected on GB. Otoliths were removed from larvae and processed without sectioning (Green et al. 2004). For larvae, otolith diameter was measured across the shortest axis to correspond with the long axis viewed in the transverse section of the juvenile otolith. The rationale for this approach was that, while increments present in the larval otolith may become indiscernible in the juvenile otolith, the relationship between increment number and diameter would remain fixed. Consequently, if the width were measured along the same axis in both the larval and juvenile otolith, then the relationship between widths and increment counts derived from larval otoliths could be applied to the inner portion of the juvenile otolith.

A subsample of juvenile otoliths was read independently by a second reader. The precision of and differ- ences in daily increment counts between otolith readers were tested by average percent error methods (Beamish \& Fournier 1981, Chang 1982), and by a chisquare method (Hoenig et al. 1995).

Age, hatch dates and growth rate. For purposes of calculation and discussion, the YOY haddock data have been divided by catch location into 2 stocks according to the standard stock definitions of the NEFSC, referred to as the GB and GOM stocks (Fig. 1). The GOM stock includes juveniles collected on the southwestern Scotian Shelf, where relatively high numbers were collected in the vicinity of Browns Bank. This putative stock structure was derived from tagging studies, meristic data, age composition and growth data (Clark et al. 1982, Begg 1998).

Age to the nearest day was calculated for each otolith by adding the number of increments counted to those estimated for the inner unreadable area using the relationship between diameter and daily increment number determined for haddock larvae. Hatch date was determined by subtracting the age from the capture date. Growth rate (GR) in $\mathrm{mm} \mathrm{d}^{-1}$ was calculated using the fork length (FL) data (nearest $\mathrm{cm}$ ) and age in days:

$$
\mathrm{GR}=\mathrm{FL} / \text { Age }
$$

Since fish length was only recorded to the nearest centimeter, more accurate growth rate determinations were not possible.

The HDFs of juveniles were constructed by summing the number of individuals hatched over intervals of $10 \mathrm{~d}$ to 1 mo depending upon the analysis. Since all collections were made over a relatively short period each fall, and since juveniles experience relatively low daily mortality rates compared to larvae, no correction was made for mortality effects (Campana 1996). This was the conservative approach since any correction for mortality would have moved the distributions toward the left (earlier in the year), resulting in greater separation between HDFs of juveniles and eggs. For comparison with the HDF of eggs (Mountain et al. 2003), juvenile hatch dates were summed over $10 \mathrm{~d}$ intervals. To estimate relative survival, the HDFs of eggs and juveniles were first converted to relative HDFs by dividing the number in each interval by the total number in the sample. The relative HDF of juveniles was then divided by the relative HDF of eggs for each $10 \mathrm{~d}$ interval (Fortier \& Quinonez-Velazquez 1998). HDFs based on late-stage egg abundance were available for the years 1995 and 1999 (Mountain et al. 2003, D. Mountain pers. comm.). Briefly, they estimated daily hatching abundance using data on late egg abundance from monthly cruises completed on GB between January and May of each year. Late egg abundance was projected forward in time using egg mortality rates to estimate abundance at hatching and normalized to daily 
values using stage duration. We created composite relative HDFs by summing, across years, the number of larvae hatched in each $10 \mathrm{~d}$ interval and dividing by the total. To allocate production of juveniles over the spawning season, the relative HDFs of YOY juveniles were multiplied by the estimates of the beginning of the year Age 1 abundance estimate from Virtual Population Analysis (VPA) (Brodziak et al. 2002).

\section{RESULTS}

\section{Otolith increment counts}

The mean increment counts were not significantly different between the primary otolith reader and a second otolith reader (198 increments and 201 increments, respectively; Student's $t$-test: $t_{\text {stat }}=0.67, \mathrm{df}=27, \mathrm{p}=0.51$ ). The average error between readers was $6.92 \%$ with a $\mathrm{CV}$ of $8.63 \%$. For $82 \%$ of the samples, error was less than $10 \%$ between readers. A test of symmetry applied to increment counts was not significant $\left(\chi^{2}=15, \mathrm{df}=14\right.$, $p=0.27$ ), indicating that neither reader was consistently reading higher or lower. It was, therefore, determined that, with the exception of the central amorphous region, the otolith microstructure of YOY haddock was largely unambiguous for purposes of estimating age.

Data on sagittal ring count and diameter in larval haddock were fit to the linear relationship:

$$
\begin{gathered}
\text { No. of increments }=0.148 \text { (diameter })+8.852 \\
\left(\mathrm{n}=54, \mathrm{R}^{2}=0.95\right)
\end{gathered}
$$

where the diameter was measured in micrometers along the shortest axis (Fig. 2). The mean diameter of the central amorphous region in YOY haddock was $84.4 \pm 24.5 \mu \mathrm{m}$, corresponding to 21 increments. The mean estimated age of YOY haddock sampled was

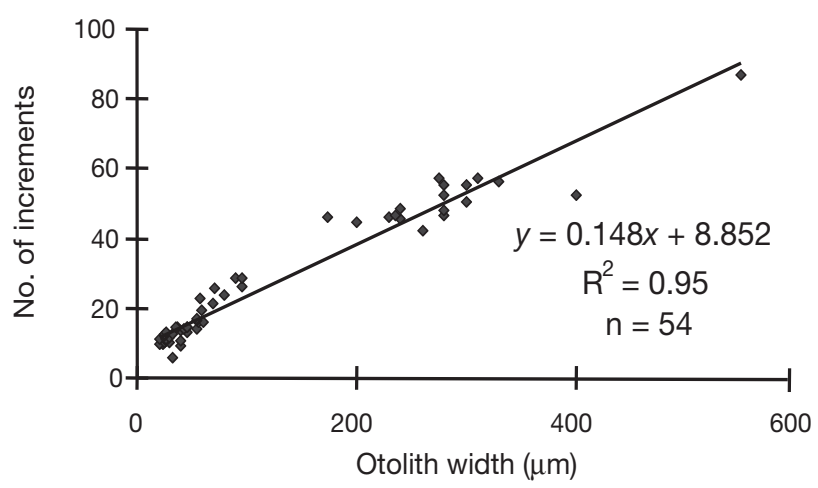

Fig. 2. Melanogrammus aeglefinus. Relationship between otolith diameter and ring count in larval haddock collected on Georges Bank
$211 \mathrm{~d}$, based on increments actually counted (mean = 190) plus those estimated from the width of the amorphous central region. The mean number of increments that was estimated based on the diameter of the central amorphous region, rather than actually counted, represented $10 \%$ of the estimated age, with a range of 4.7 to $20.2 \%$.

For all years pooled, FL $(\mathrm{cm})$ was linearly related to age (d) according to the equation:

$$
\mathrm{FL}=0.054 \text { (Age) }+2.662\left(\mathrm{n}=484, \mathrm{R}^{2}=0.45\right)
$$

The relationship between age and length observed in this study was compared to that found by Bolz \& Lough (1988) for larval and pelagic juvenile fish, and Clark et al. (1982) for adult fish (Fig. 3). The bulk of our YOY haddock data falls at a slightly smaller length-atage than is predicted by the published models. It should be noted that the Gompertz model used by Bolz \& Lough (1988) does not reflect a 'leveling off' of the standard length/time relationship seen in their data on fish greater than $50 \mathrm{~mm}$ in standard length. Another factor to consider is that Bolz \& Lough (1988) corrected their length data for shrinkage. Our lengths were not corrected for shrinkage and should reflect a somewhat smaller size-at-age.

\section{Hatch dates}

A 2-way analysis of variance (ANOVA) using the model:

Hatch date $=$ Year, Stock, Stock $\times$ Year

showed significant effects of both year $(p<0.0001)$ and stock ( $p<0.001)$, but not the interaction term $(p=0.5)$. Due to the relatively small sample size from the GOM for the years 1995 through 1997, current understand-

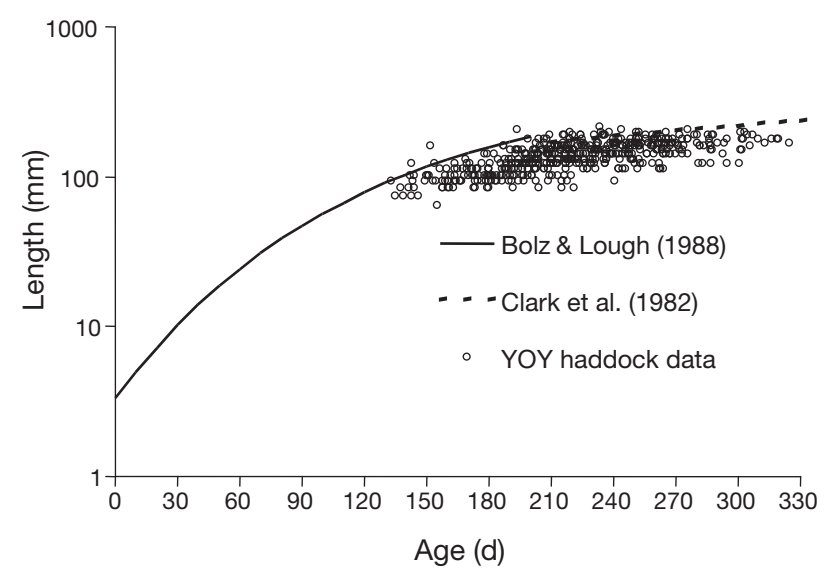

Fig. 3. Melanogrammus aeglefinus. Size-at-age (d post hatch) for Georges Bank haddock. The Gompertz curve for larvae is from Bolz \& Lough (1988). The Von Bertalanffy curve for juveniles and adults is from Clark et al. (1982) 
ing of stock boundaries, the lack of egg hatching data for GOM and the focus of the US GLOBEC Program on GB, we consider the 2 regions separately.

\section{Georges Bank stock}

Means and ranges of hatch date, growth rate and length at capture of the GB stock are presented in Table 1. YOY haddock juveniles captured in the NEFSC autumn trawl survey, for all years (1995 to 1999) pooled, had a mean hatch date of March 4. HDFs varied considerably among years (Fig. 4). Excluding 1998 data, which had a large sample size and relatively late peak in hatch distribution (March 15), the mean hatch date was February 21 (Fig. 5). A comparison of the HDF for 1998 with all other years pooled using the Kolmogorov-Smirnov 2-sample test (a test of whether the distributions could have come from the same pop-

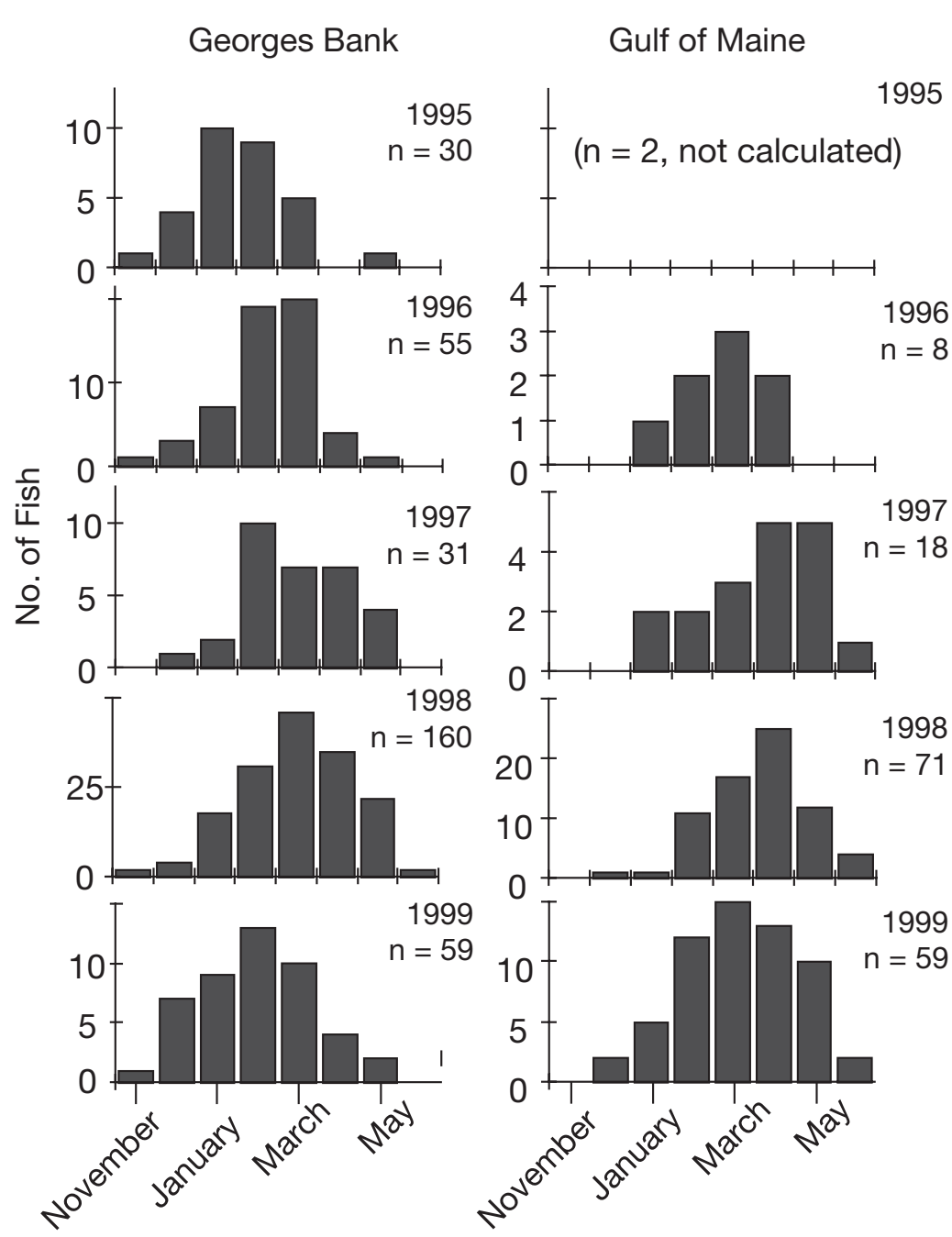

Fig. 4. Melanogrammus aeglefinus. Hatch date distributions by year for YOY haddock collected during the NEFSC fall groundfish surveys (1995 to 1999), divided into the 2 stock regions ulation, Sokal \& Rohlf 1995) indicated a significant difference $(\mathrm{p}<0.001)$ in the distributions. ANOVA indicated that mean hatch date in 1998 was significantly different (later) from that of 1995 and 1999.

The approximate mean daily growth rate (all years pooled) was $0.67 \mathrm{~mm} \mathrm{~d}^{-1}$, with an individual range of 0.41 to $1.14 \mathrm{~mm} \mathrm{~d}^{-1}$ (Table 1). Growth rate was lowest, on average, for the 1995 year-class and most rapid in the 1996 year-class $\left(0.64\right.$ and $0.70 \mathrm{~mm} \mathrm{~d}^{-1}$, respectively; $\mathrm{p}<0.05)$. There were no significant differences between the mean growth rates of any other yearclasses examined.

\section{Gulf of Maine stock}

Means and ranges of hatch date, growth rate and length at capture of the GOM stock are presented in Table 2. YOY haddock juveniles captured in the NEFSC autumn trawl survey, for all years (1995 to 1999) pooled, had a mean hatch date of March 29. ANOVA indicated that mean hatch dates were not significantly different among years in the GOM region. Sample sizes for this stock were very small for 1995 to 1997 (Table 2, Fig. 4).

Mean daily growth rate for GOM juveniles (all years pooled) was $0.66 \mathrm{~mm} \mathrm{~d}^{-1}$, with an individual range of 0.43 to $0.96 \mathrm{~mm} \mathrm{~d}^{-1}$ (Table 2). ANOVA indicated that mean growth rates were not significantly different among years in the GOM region.

\section{Georges Bank vs. Gulf of Maine}

Limited samples from 1995 through 1997 in the GOM limited year-by-year comparisons to 1998 and 1999. In both of these years, the mean hatch date was significantly earlier for juveniles collected on GB compared to the GOM (ANOVA, p < 0.01). The mean hatch date (1995 to 1999 taken together) of GB juveniles was significantly earlier than that of the GOM $\left(t_{\text {stat }}=-6.46\right.$, df $\left.=482, \mathrm{p}<0.001\right)$. On average, the mean hatch dates were offset by almost 1 mo (Table 2). A comparison of the GB and GOM HDFs indicated a highly significant difference ( $p<0.001$, Kolmogorov-Smirnov 2 -sample test). Mean growth rate and 
Table 1. Melanogrammus aeglefinus. Summary data for YOY haddock of the Georges Bank stock caught during the NEFSC autumn bottom trawl surveys from 1995 to 1999. Data on stratified mean catch per tow (numbers), recruitment (Age 1, beginning year stock size from Virtual Population Analysis [VPA] in millions), spawning stock biomass (SSB thousands of metric tons, kmt) and recruitment survival (recruitment/SSB) are from Brodziak et al. 2002. Mean hatch dates with a letter in common are not significantly different (ANOVA $\mathrm{p}<0.05$ )

\begin{tabular}{|c|c|c|c|c|c|c|c|c|c|c|c|}
\hline \multirow[t]{2}{*}{ Year } & \multirow[t]{2}{*}{$\mathrm{n}$} & \multicolumn{2}{|c|}{$\begin{array}{l}\text { Fork length } \\
\text { (cm) }\end{array}$} & \multicolumn{2}{|c|}{$\begin{array}{c}\text { Hatch date } \\
(\mathrm{mo} / \mathrm{d})\end{array}$} & \multicolumn{2}{|c|}{$\begin{array}{c}\text { Growth rate } \\
\left(\mathrm{mm} \mathrm{d}^{-1}\right)\end{array}$} & \multirow{2}{*}{$\begin{array}{l}\text { Stratified } \\
\text { mean } \\
\text { catch/ } \\
\text { tow }\end{array}$} & \multirow{2}{*}{$\begin{array}{l}\text { Recruit- } \\
\text { ment } \\
\text { (millions) }\end{array}$} & \multirow[t]{2}{*}{$\begin{array}{l}\mathrm{SSB} \\
(\mathrm{kmt})\end{array}$} & \multirow{2}{*}{$\begin{array}{l}\text { Recruitment } \\
\text { survival } \\
\text { VPA Age 1/ } \\
\text { SSB }\end{array}$} \\
\hline & & Mean & Range & Mean & Range & Mean & Range & & & & \\
\hline 1995 & 30 & 15 & $8-19$ & $1 / 31^{\mathrm{c}}$ & $11 / 22-5 / 14$ & 0.64 & $0.44-0.77$ & 2.27 & 10.91 & 24.32 & 0.45 \\
\hline 1996 & 55 & 16 & $9-21$ & $2 / 22^{b, c}$ & $11 / 17-5 / 7$ & 0.70 & $0.46-0.96$ & 1.31 & 19.94 & 30.38 & 0.66 \\
\hline 1997 & 35 & 14 & $9-22$ & $3 / 18^{a}$ & $12 / 28-5 / 28$ & 0.67 & $0.41-1.14$ & 0.32 & 14.20 & 37.27 & 0.38 \\
\hline 1998 & 160 & 15 & $8-23$ & $3 / 15^{a, b}$ & $11 / 14-6 / 8$ & 0.67 & $0.42-1.12$ & 4.32 & 39.48 & 42.52 & 0.93 \\
\hline 1999 & 46 & 17 & $10-22$ & $2 / 17^{\mathrm{c}}$ & $11 / 27-5 / 12$ & 0.67 & $0.45-0.91$ & 1.82 & 17.68 & 50.54 & 0.35 \\
\hline Overall & 326 & & & $3 / 4$ & $11 / 14-6 / 8$ & 0.67 & $0.41-1.14$ & 2.01 & 20.44 & 37.01 & 0.55 \\
\hline
\end{tabular}

Table 2. Melanogrammus aeglefinus. Mean and ranges of fork length, hatch date and average daily growth rates of YOY haddock of the Gulf of Maine stock caught during the NMFS autumn bottom trawl surveys from 1995 to 1999. Mean hatch dates with a letter in common are not significantly different (ANOVA $\mathrm{p}<0.05$ )

\begin{tabular}{|c|c|c|c|c|c|c|c|}
\hline \multirow[t]{2}{*}{ Year } & \multirow[t]{2}{*}{$\mathrm{n}$} & \multicolumn{2}{|c|}{ Fork length (cm) } & \multicolumn{2}{|c|}{ Hatch date $(\mathrm{mo} / \mathrm{d})$} & \multicolumn{2}{|c|}{ Growth rate $\left(\mathrm{mm} \mathrm{d}^{-1}\right)$} \\
\hline & & Mean & Range & Mean & Range & Mean & Range \\
\hline 1995 & 2 & 12 & $11-12$ & $3 / 5^{\mathrm{a}}$ & $2 / 27-3 / 11$ & 0.52 & $0.52-0.53$ \\
\hline 1996 & 8 & 14 & $11-17$ & $3 / 13^{a}$ & $1 / 31-4 / 15$ & 0.67 & $0.58-0.91$ \\
\hline 1997 & 18 & 12 & $9-21$ & $4 / 9^{\mathrm{a}}$ & $1 / 06-6 / 10$ & 0.65 & $0.46-0.88$ \\
\hline 1998 & 71 & 14 & $7-20$ & $4 / 4^{\mathrm{a}}$ & $12 / 24-6 / 8$ & 0.67 & $0.44-0.96$ \\
\hline 1999 & 59 & 14 & $8-21$ & $3 / 23^{\mathrm{a}}$ & $12 / 11-6 / 13$ & 0.65 & $0.43-0.93$ \\
\hline Overall & 158 & & & $3 / 29$ & $12 / 11-6 / 13$ & 0.66 & $0.43-0.96$ \\
\hline
\end{tabular}

length-at-age were not significantly different between the 2 stocks when the data from all years were pooled by stock ( $t_{\text {stat }}=1.16$, df $=482, \mathrm{p}=0.24$; ANOVA, $F=0.15$ ) (Tables $1 \& 2$ ).

\section{Relative survival: GB stock}

We used HDFs generated from late-stage egg abundance on GB (Mountain et al. 2003) together with our HDFs for Georges Bank YOY juveniles to generate relative survivorship curves for each of the 5 years and a composite of all years combined. Due to the relatively small sample size in most years, we show 2 survivorship curves, one with all years combined except 1998 (Fig. 5a) and a second for 1998 (Fig. 5b), the year with the largest sample size and the highest recruitment in the time series. For all individual years and the composite, peak hatch of survivors was well ahead of that of the population as a whole (eggs), and relative survival was highest for individuals hatched in the early portion of the curve.

\section{DISCUSSION}

The concept of 'stock' in the fisheries literature has been variably defined. One current definition of the 'stock concept' is 'semi-discrete groups of fish with some definable attributes of interest to managers' (Begg et al. 1999a). Stock identification is crucial to stock assessment and management, as overfishing and depletion of less productive stocks can result from failure to recognize the stock structure of an exploited species (Begg et al. 1999a). Stock identification is also important when seeking to study and understand recruitment processes, since the stock is the basic reproductive unit and different factors, both environmental and biotic, may be important to different stocks. Despite this significance, identification of stock structure has proven difficult in both theory and practice, and current stock definitions are subject to revision. The current stock definitions of the northwest Atlantic haddock population are reviewed by Begg (1998). Here, we follow current practice by treating haddock within the study area as 2 stocks, one on GB 

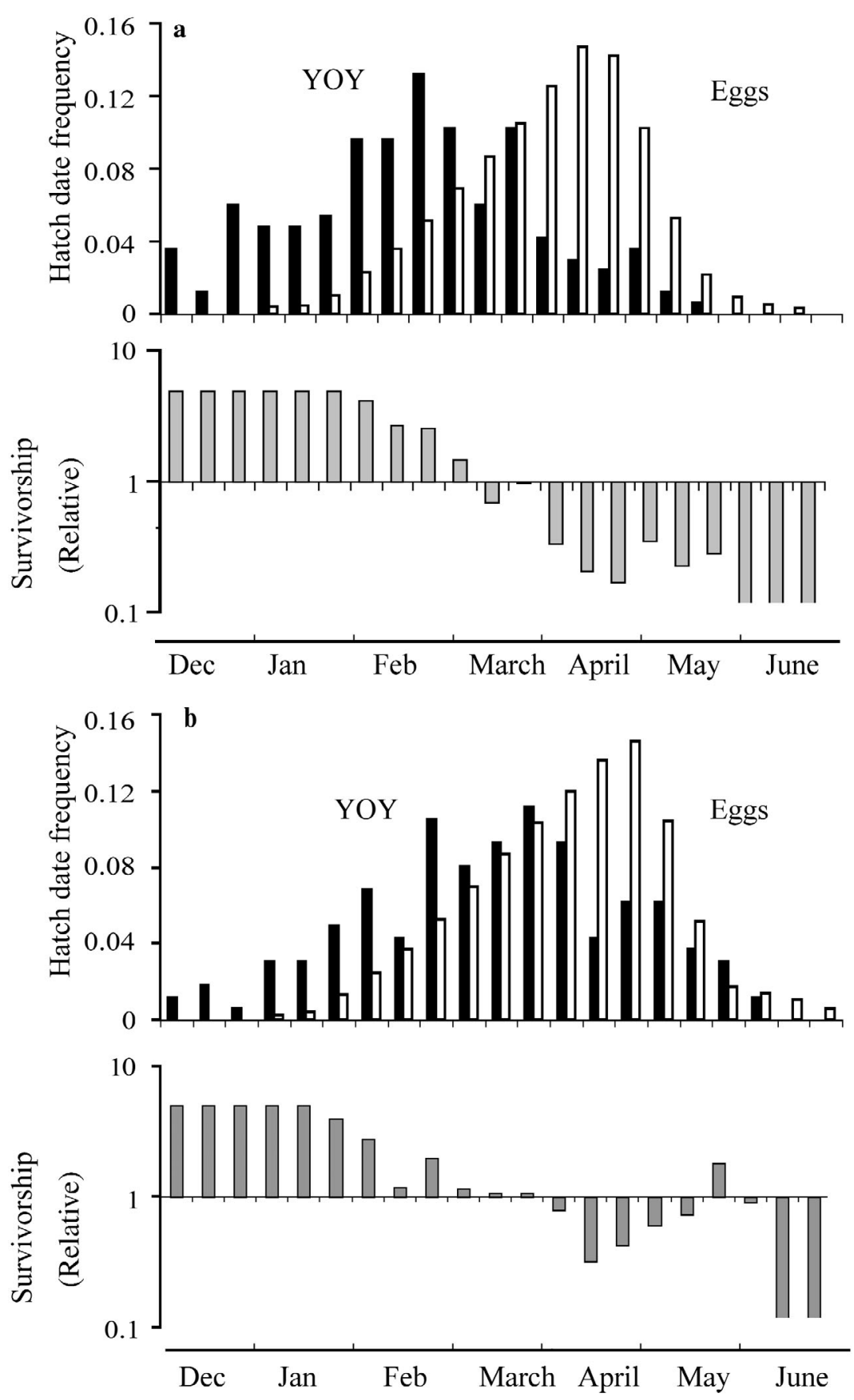

Fig. 5. Melanogrammus aeglefinus. Relative hatch date frequencies (HDF; $10 \mathrm{~d}$ intervals) of Georges Bank haddock based on late-stage eggs (Mountain et al. 2003) and on YOY haddock with relative survival (relative HDF juveniles/ relative HDF eggs) for (a) 1995, 1996, 1997 and 1999 combined and for (b) 1998

and south, and a second in the GOM and southern Scotian Shelf (Brown \& Munroe 2000). It has been hypothesized that there are 2 spawning components on GB, one along the Great South Channel (West) and the other on the Northeast Peak (East) (Smith \& Morse 1985, Begg et al. 1999b, Begg \& Brown 2000). Genetic distance measures, based on 4 microsatellite loci, suggest that haddock spawning on Nantucket Shoals to the west of the Great South Channel may be genetically distinct from haddock spawning on GB and the remainder of the GOM (Lage et al. 2001).

Our data on YOY haddock birth dates lend support to the current management practice of treating GB and the GOM as distinct stocks regions, but not the division between western and eastern GB. The year-to-year consistency of lag time between peak hatch dates of surviving YOY haddock juveniles collected from the GB and GOM stock regions is also in agreement with the somewhat later annual peak egg abundance in the GOM/Scotian Shelf regions compared to GB (Berrien \& Sibunka 1999) and the roughly 1 mo difference in peak spawning times reported for $\mathrm{GB}$ and Browns Bank (Page \& Frank 1989). Moreover, our data are consistent with the observation that spawning times were more variable among years on GB compared to Browns Bank (Page \& Frank 1989). We found no significant differences in growth rates of YOY haddock among regions.

\section{Temporal patterns in recruitment}

Examination of the patterns in HDFs at different life-history stages and relative survival coupled with environmental data collected over the same period may help to elucidate the factors affecting recruitment variability in haddock. The relatively smooth, broad and unimodal HDFs of YOY demersal juveniles observed each year suggest that haddock recruitment is not particularly episodic in any given year. While the relatively small sample size in some years limited the degree of resolution possible, the considerably larger sample of the 1998 year class revealed a broad and relatively smooth distribution of birth dates when binned into $10 \mathrm{~d}$ intervals. HDFs based on late egg stage abundance sampled as part of the GLOBEC broad-scale cruises between January and June of 1995 to 1999, indicated that haddock hatched between January and May, with a pronounced peak in the first half 
of April in most years (Mountain et al. 2003, D. Mountain pers. comm.). The April timing of peak hatch is consistent with the April peak in egg abundance reported for the period 1977 to 1987 (Berrien \& Sibunka 1999) and with the timing of peak haddock larval abundance between April and May on GB (Sherman et al. 1984). The duration of the egg stage is dependent on water temperature, with hatching occurring within 10 to $20 \mathrm{~d}$ at the temperatures typically experienced by eggs on GB (Page \& Frank 1989).

The high relative survival to the fall of individuals from the first half of the spawning season and the low relative survival of individuals from the later part of the spawning season suggest that conditions were more favorable for recruitment of haddock spawned early. While the small sample size in some years limits the utility of year-by-year comparisons, the same pattern was seen for all 5 years and the composite. Both maternal and environmental factors may contribute to the apparent shift in HDFs toward early spawned individuals. Haddock are batch spawners; egg size increases with female size and decreases as the spawning season progresses and the water warms (Hislop 1978, 1988). Spawning of larger (older) repeat spawners earlier in the season, as compared to first time spawners, may also contribute to the high relative survival observed early in the season. A review of the fisheries literature (Trippel et al. 1997) suggests that large females are more fecund, commonly start spawning earlier, continue spawning longer and produce larger, moreviable eggs than do smaller individuals.

Seasonal patterns in photoperiod, water temperature, food availability and predation rates are likely contributors to the pattern seen in relative survival. Winter spawning may be an adaptation in haddock to reduce predation pressure on planktonic eggs and larvae, if their predators are less abundant or less active in winter (Fortier \& Quinonez-Velazquez 1998). An analysis of the spatial and temporal overlap of haddock and cod larvae with 2 abundant planktivorous fish, Atlantic mackerel and herring, indicated a high degree of overlap and potential predation by herring on haddock larvae during April and May on the southern flank of GB (Garrison et al. 2000). The timing of the spring migration of both Atlantic mackerel Scomber scombrus (late May to June) and herring Clupea harengus (April to mid May) is such that haddock larvae hatched in the early part of the season would be expected to have grown through the size of maximum vulnerability by the time these fish predators are most abundant on GB. Consequently, haddock eggs and larvae from the latter part of the spawning period would appear to have greater exposure and vulnerability to Atlantic mackerel and herring compared to those produced early in the season.
The same is likely true for abundant invertebrate predators on GB including chaetognaths (Sagitta spp.), cnidarians (hydrozoan and scyphozoan medusae), euphausiids (Meganyctiphanes norvegica and Euphausia krohni), gammarid amphipods and ctenophores (Davis 1984). All these abundant invertebrate predators, with the possible exception of euphausiids, showed seasonal peaks in abundance on GB no earlier than May. The positive relationship among metabolic rates, consumption and temperature would also contribute to rising predation rates as waters warmed in the spring and summer. Since these potential predators on fish larvae also feed on the same zooplankton food resources as haddock larvae and pelagic juveniles, they may also impact food availability particularly in May and June.

Available data on the distribution and abundance of larval haddock (Lough \& Bolz 1989) and fish, and invertebrate predators (Davis 1984, Sullivan \& Meise 1996, Garrison et al. 2000) together with our data on relative survival of haddock over the spawning season lend support to the hypothesis that predation pressure will be higher for fish hatched later in the season (Fortier \& Quinonez-Velazquez 1998). Early settlement onto the central portion of GB may also confer a survival advantage to fish spawned early in the season, due to post-settlement competition for food and shelter from predators. Visual observations of Atlantic cod in coastal waters indicated that growth and territory size increased with fish size and early settlement (Tupper \& Boutilier 1995). The disappearance of YOY Atlantic cod and haddock from large areas of the central GB, and their concentration on a large pebble-gravel deposit on the northeastern edge by the late summer (Lough et al. 1989) suggest that suitable habitat for growth and survival may be limited, possibly favoring large haddock that had settled early.

Although early-stage haddock larvae are most abundant between April and May on GB, larger and considerably older larvae, that may avoid nets typically used for larval sampling, are caught during this period (e.g. Lough \& Potter 1993, J. Green pers. comm.). Based on the patterns seen in relative survival and the HDFs of surviving YOY haddock, it appears that these less abundant, older larvae seen in April and May comprise the bulk of the demersal-juvenile survivors caught on GB in the fall. The timing of the critical mortality that results in the disproportional representation in the fall of fish hatched early in the season is unknown. However, some suggestion of a shift to earlier hatch dates can be seen in the HDFs of 41 to $80 \mathrm{~d}$ old haddock compared to 0 to $20 \mathrm{~d}$ old larvae (Fortier \& QuinonezVelazquez 1998). Although there appears to be no comparable published data on HDFs of YOY demersal haddock for $\mathrm{GB}$, it is possible using an age-length 
relationship (Bolz \& Lough 1988) to estimate the hatch dates of haddock collected during the summer on GB. The mean length of YOY haddock caught with a bottom trawl on GB in July 1985 was $7.1 \mathrm{~cm}$ (Lough \& Potter 1993), corresponding to an age of $115 \mathrm{~d}$ and a hatch date of 23 March. In August 1985, mean length was $14 \mathrm{~cm}$, corresponding to an age of $168 \mathrm{~d}$ and a hatch date of 1 March. These limited data lend support to our finding that YOY haddock surviving to the fall come predominantly from the early part of the spawning season.

Insufficient data on the abundance of late larval and pelagic juvenile haddock in the GOM/GB has precluded a full life-table approach to determine the timing of critical mortality, as has been done for the northern anchovy Engraulis mordax, walleye pollock and several other species (Peterman et al. 1988, Bailey et al. 1996). However, an analysis of 3 year-classes (1983, $1984,1985)$ suggested that mortality between the larval and pelagic juvenile stages was inversely correlated with year-class strength of cod and haddock off Southwest Nova Scotia (Campana et al. 1989).

\section{The 1998 year-class on Georges Bank}

The 1998 year-class was the largest on GB in our time series (Table 1) and possibly the largest since 1978 (Werner et al. 1999, Brown \& Munroe 2000). The 1998 year-class was well represented in our data, particularly in the GB region. Recruitment survival (Age 1 abundance/spawning stock biomass) was also particularly high in 1998, again the highest in our time series. The mean hatch date of YOY haddock collected in the fall of 1998 was approximately 1 mo later than the mean for all other years combined (1995, 1996, 1997 and 1999, Figs. 4 to 6), and significantly later than in 1995 and 1999. The 1997 YOY juveniles had a comparably late mean hatch date, but a very low sample size.

Our relative HDFs, together with an index of recruitment, can be used to allocate production of a year-class over the spawning season. For this purpose, we used the beginning-year stock size based on VPA (Brodziak et al. 2002). We assumed that the HDFs did not change between the fall survey and the beginning of the following year. More survivors were produced in each of the first 6 mo of 1998 compared to the monthly average of the remaining years (Fig. 6). The shift in hatch dates to later in the season among survivors of the strong 1998 year-class suggests that survival of haddock hatched in April and May of 1998 was particularly enhanced compared to years producing poor to average year-classes (1995, 1996, 1997, and 1999). Even with this shift in the mean hatch date of survivors towards the middle of the season, survivorship in the

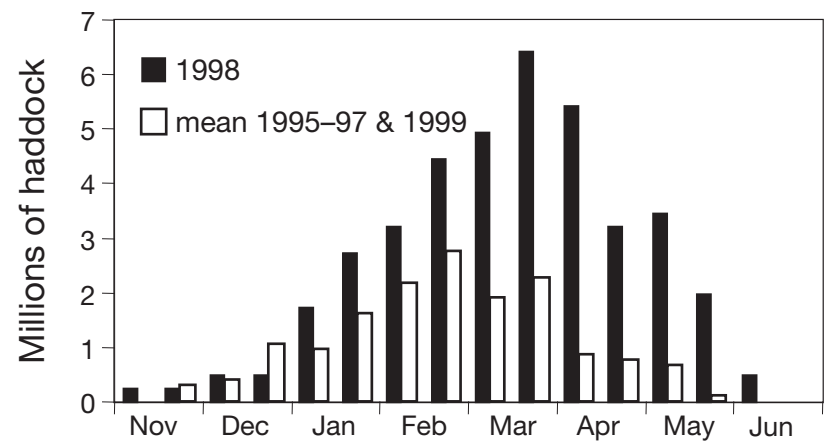

Fig. 6. Melanogrammus aeglefinus. Production of beginning year, Age 1 juvenile haddock (millions) in the Georges Bank region allocated to time of hatching, with a comparison of 1998 and the mean of 1995, 1996, 1997 and 1999. Relative hatch date frequencies were multiplied by the estimated Age 1 abundance for the corresponding year-classes from Virtual Population Analysis (VPA) (Brodziak et al. 2002) to estimate production in millions of fish

1998 year-class was still highest for individuals originating from the early portion of the season.

Transport of haddock eggs, larvae or juveniles from the GOM/Southern Scotian Shelf onto GB may have contributed to the later mean hatch date seen in juveniles of the strong 1998 year-class compared to other years on GB. However, large-scale transport of eggs onto GB should have a comparable effect on the HDFs based on late-stage eggs, which was not the case. Examination of hatch date distributions in conjunction with environmental data, and egg and larval data may help elucidate factors contributing to good recruitment of haddock.

Although prey availability and growth of haddock larvae in 1998 was among the highest in the $5 \mathrm{yr}$ GLOBEC time series (Buckley \& Durbin 2004), estimated growth of YOY juveniles caught on GB in 1998 was average. While rapid growth during the larval and early juvenile period may contribute to enhanced survival (Houde 1987, Campana 1996), density-dependent growth during the juvenile period may offset any early growth advantage of abundant year-classes. Off Southwest Nova Scotia, growth of haddock and cod larvae was inversely related to early larval mortality and independent of abundance, while juvenile growth was proportional to mortality and inversely related to abundance (Campana et al. 1989). Growth of haddock during the juvenile stage has been shown to exhibit density dependence (Ross \& Nelson 1992, Marshall \& Frank 1999) that results in temporally persistent trends in length when yearclasses are compared. Measurable differences in length-at-age among older juvenile and adult fish may be more common than among YOY juveniles, since the strength of the size-selective forces of pre- 
dation and starvation mortality may decrease once a critical size is reached, likely by the end of the first year of life.

Our results do not imply that larval and early juvenile growth is unrelated or unimportant to mortality and subsequent recruitment. If the shift in HDFs of survivors (YOY juveniles) towards the earlier portion of the hatching curve of the population (eggs) is due to an increase in predation pressure as the season progresses, then rapid growth through the highly vulnerable early-life stages should result in increased survival.

\section{CONCLUSION}

Our findings indicate that haddock spawned early in the season on GB have a higher probability of surviving to the fall than individuals spawned during the middle and latter part of the season. This conclusion assumes that YOY haddock caught in the NEFSC fall groundfish survey comprise a representative sample of the GB population and, moreover, that our estimated ages are accurate to within a few weeks. Compared to most other years, the HDF of YOY haddock from the large 1998 year-class was shifted toward later in the year, more closely matching that of late-stage eggs. Nevertheless, survival was still highest for individuals from the early part of the hatching curve compared to those hatching in the latter portion of the curve. In 1998, more YOY juvenile haddock were produced in each month between January and June compared to the composite of the remaining 4 years that produced small to average year-classes, indicating that the factors favoring strong recruitment operate over a period of several months. This observation and the relatively broad and smooth HDFs of YOY juveniles suggest that recruitment of GB haddock is not particularly episodic within the year. More information on the timing and agent(s) of the shift in HDFs from April at hatch to the first part of March or earlier in demersal juveniles could provide new insights into the factors affecting recruitment of haddock on GB.

Acknowledgements. The authors would like to thank the Fisheries Biology group at NMFS/NER/NEFSC Woods Hole for all their help in the collection and processing of haddock otoliths. Special thanks to J. Burnett for his general goodwill and helpfulness, particularly in answering cruise-related questions. Many thanks to K. Lang for advice and assistance in methods development, facilitation of lab and equipment access, and for aging a subsample of otoliths for comparison. We would also like to thank members of the NMFS/NER/ NEFSC Narragansett Laboratory: J. Green, S. Brownell, and R. Jones for access to their count data from larval and pelagic juvenile haddock, and for sharing the image analysis equipment; B. Burns for methods development assistance; and
L. Natanson for the use of the sanding wheel. This work was supported by the US GLOBEC, Northwest Atlantic Georges Bank Program jointly funded by NOAA COP and NSF. This is GLOBEC contribution 248.

\section{LITERATURE CITED}

Azarovitz TR (1981) A brief historical review of the Woods Hole Laboratory trawl time series. Can Spec Pub Fish Aquat Sci 58:62-69

Bailey KM, Brodeur RD, Hollowed AB (1996) Cohort survival patterns of walleye pollock, Theraga chalcogramma, in the Shelikof Strait, Alaska: a critical factor analysis. Fish Oceanogr 5 (Suppl 1):179-188

Beamish RJ, Fournier DA (1981) A method for comparing the precision of a set of age determinations. Can J Fish Aquat Sci 38:982-983

Begg GA (1998) A review of stock identification of haddock, Melanogrammus aeglefinus, in the northwest Atlantic Ocean. Mar Fish Rev 60:1-15

Begg GA, Brown RW (2000) Stock identification of haddock Melanogrammus aeglefinus on Georges Bank based on otolith shape analysis. Trans Am Fish Soc 129:935-945

Begg GA, Friedland KD, Pearce JB (1999a) Stock identification and its role in stock assessment and fisheries management: an overview. Fish Res 43:1-8

Begg GA, Hare JA, Sheehan DD (1999b) The role of life history parameters as indicators of stock structure. Fish Res 43:141-163

Berrien P, Sibunka J (1999) Distribution patterns of fish eggs in the U.S. northeast continental shelf ecosystem, 1977-1987. NOAA (Natl Ocean Atmos Adm) Tech Rep NMFS (Natl Mar Fish Serv) 145:1-310

Bolz GR, Lough RG (1988) Growth through the first 6 months of Atlantic cod, Gadus morhua, and haddock, Melanogrammus aeglefinus, based on daily otolith increments. Fish Bull US 86:223-235

Brodziak J, Thompson M, Brown R (2002) Georges Bank haddock. In: Assessment of 20 northeast groundfish stocks through 2001: a report of the Groundfish Assessment Review Meeting (GARM), Northeast Fisheries Science Center (NEFSC), Woods Hole, MA, October 8-11, 2002. NEFSC Ref Doc 02-16. National Marine Fisheries Service, Woods Hole, MA, p 36-59. Also available at: http:// www.nefsc.gov/nefsc/publications/crd/crd0216/

Brown RW, Munroe JN (2000) Stock assessment of Georges Bank haddock, 1931-1999. A report of the 3rd Transboundary Resources Assessment Committee Meeting. NEFSC Ref Doc 00-12. National Marine Fisheries Service, Northeast Science Center, Woods Hole, MA, p 1-119

Buckley LJ, Durbin EG (2004) Annual and inter-annual trends in the zooplankton prey and growth of Atlantic cod (Gadus morhua) and haddock (Melanogrammus aeglefinus) larvae on Georges Bank. ICES CM2004/O:08

Campana SE (1996) Year-class strength and growth rate in young Atlantic cod Gadus morhua. Mar Ecol Prog Ser 135: $21-26$

Campana SE, Frank KT, Hurley PCF, Kohler PA, Page FH, Smith PC (1989) Survival and abundance of young Atlantic cod (Gadus morhua) and haddock (Melanogrammus aeglefinus) as indicators of year-class strength. Can J Fish Aquat Sci 46:171-182

Chang WYB (1982) A statistical method for evaluating the reproducibility of age determination. Can J Fish Aquat Sci 39:1208-1210

Clark SH, Overholtz WJ, Hennemuth RC (1982) Review and 
assessment of the George Banks and Gulf of Maine haddock fishery. J Northwest Atl Fish Sci 3:1-27

Davis CS (1984) Predatory control of copepod seasonal cycles on Georges Bank. Mar Biol 82:31-40

Fortier L, Quinonez-Velazquez C (1998) Dependence of survival on growth in larval pollock Pollachius virens and haddock Melanogrammus aeglefinus: a field study based on individual hatchdates. Mar Ecol Prog Ser 174:1-12

Garrison LP, Michaels W, Link JS, Fogarty MJ (2000) Predation risk on larval gadids by pelagic fish in the Georges Bank ecosystem. I. Spatial overlap associated with hydrographic features. Can J Fish Aquat Sci 57:2455-2469

Green J, Jones R, Brownell S (2004) Age and growth of larval cod and haddock on Georges Bank during 1995 and 1996. Mar Ecol Prog Ser 283:255-268

Hislop JRG (1978) Observations on the effects of feeding level on growth and reproduction in haddock, Melanogrammus aeglefinus (L.) in captivity. J Fish Biol 13:85-98

Hislop JRG (1988) The influence of maternal length and age on the size and weight of eggs and the relative fecundity of haddock, Melanogrammus aeglefinus in British waters. J Fish Biol 32:923-930

Hoenig JM, Morgan MJ, Brown CA (1995) Analysing differences between two age determination methods by tests of symmetry. Can J Fish Aquat Sci 52:364-368

Houde ED (1987) Fish early life dynamics and recruitment variability. Am Fish Soc Symp 2:17-29

Kendall AW Jr., Schumacher JD, Kim S (1996) Walleye pollock recruitment in Shelikof Strait: applied fisheries oceanography. Fish Oceanogr 5:4-18

Lage C, Purcell M, Fogarty M, Kornfield I (2001) Microsatellite evaluation of haddock (Melanogrammus aeglefinus) stocks in the northwest Atlantic Ocean. Can J Fish Aquat Sci 58:982-990

Lough RG, Bolz GR (1989) The movement of cod and haddock larvae onto the shoals of Georges Bank. J Fish Biol 35A:71-79

Lough RG, Potter DC (1993) Vertical distribution patterns and diel migrations of larval and juvenile haddock Melanogrammus aeglefinus and Atlantic cod Gadus morhua on Georges Bank. Fish Bull US 91:281-303

Lough RG, Valentine PC, Potter DC, Auditore PJ, Bolz GR, Neilson JD, Perry RI (1989) Ecology and distribution of juvenile cod and haddock in relation to sediment type and bottom currents on eastern Georges Bank. Mar Ecol Prog Ser 56:1-12

Marshall CT, Frank KT (1999) Implications of densitydependent juvenile growth for compensatory recruitment regulation of haddock. Can J Fish Aquat Sci 56:356-363

Mountain D, Berrien P, Sibunka J (2003) Distribution, abundance and mortality of cod and haddock eggs and larvae

Editorial responsibility: Kenneth Sherman (Contributing Editor), Narragansett, Rhode Island, USA on Georges Bank in 1995 and 1996. Mar Ecol Prog Ser 263: $247-260$

Overholtz WJ, Tyler AV (1985) Long-term responses of the demersal fish assemblages of Georges Bank. Fish Bull US 83:507-520

Page FH, Frank KT (1989) Spawning time and egg stage duration in Northwest Atlantic haddock (Melanogrammus aeglefinus) stocks with emphasis on Georges Bank and Browns Bank. Can J Fish Aquat Sci 46 (Suppl 1):68-81

Peterman RM, Bradford MJ, Lo NC, Methot RD (1988) Contribution of early life stages to interannual variability in recruitment of northern anchovy (Engraulis mordax). Can J Fish Aquat Sci 45:8-16

Polacheck T, Mountain D, McMillan D, Smith W, Berrien P (1992) Recruitment of the 1987 year class of Georges Bank haddock (Melanogrammus aeglefinus): the influence of unusual larval transport. Can J Fish Aquat Sci 49: 484-496

Ross MR, Nelson GA (1992) Influences of stock abundance and bottom-water temperature on growth dynamics of haddock and yellowtail flounder on Georges Bank. Trans Am Fish Soc 121:578-587

Sherman K, Smith W, Morse W, Berman M, Green J, Ejsymont L (1984) Spawning strategies of fishes in relation to circulation, phytoplankton production, and pulses in zooplankton off the northeastern United States. Mar Ecol Prog Ser 18:1-19

Sissenwine MP (1984) Why do fish populations vary? Report of the Dalheim Workshop on exploitation of marine communities, Berlin 1984. Life Sci Res Rep 32:59-94

Smith WG, Morse WW (1985) Retention of larval haddock Melanogrammus aeglefinus in the Georges Bank region, a gyre-influenced spawning area. Mar Ecol Prog Ser 24:1-13

Sokal RR, Rohlf FJ (1995) Biometry, 2nd edn. Freeman, New York

Sullivan BK, Meise CJ (1996) Invertebrate predators of zooplankton on Georges Bank, 1977-1987. Deep-Sea Res II 43:1503-1519

Trippel EA, Kjesbu, OS, Solemdal P (1997) Effects of adult age and size structure on reproductive output in marine fishes. In: Trippel EA, Chambers RC (eds) Early life history and recruitment in fish populations. Chapman \& Hall, London, p 33-62

Tupper M, Boutilier RG (1995) Size and priority at settlement determine growth and competitive success of newly settled Atlantic cod. Mar Ecol Prog Ser 118:295-300

Werner FE, Murawski S, Brander K (1999) Report of the workshop on ocean climate of the NW Atlantic during the 1960s and 1970s and consequences for gadoid populations. Copenhagen. ICES (Int Counc Explor Sea) Coop Res Rep 234:1-85

Submitted: March 5, 2004; Accepted: November 8, 2004 Proofs received from author(s): March 23, 2005 